\title{
Success Factors from Dutch Agricultural Cooperatives and Canadian Agricultural Cooperatives in the Food and Beverage Sector: A Comparative Analysis
}

\author{
Arthur A. Dodsworth \\ Sylvain Charlebois (Corresponding Author) \\ Director, Agri-Food Analytics Lab, Dalhousie University, Halifax, Nova Scotia, B2X 3T5, \\ Canada
}

Received: June 2, 2021 Accepted: June 17, 2021 Published: June 22, 2021

doi:10.5296/jas.v9i3.18775 URL: https://doi.org/10.5296/jas.v9i3.18775

\begin{abstract}
Dutch agricultural cooperatives have long been successful in their business growth throughout Europe. With more farmers forming cooperatives that supply locally produced food and beverage products into national and international markets, there is no question that the Dutch are successful at forming agricultural cooperatives. The use of vertical coordination throughout their supply chains combined with the country's geography provides the opportune place for food and beverage production. However, there is no standard set of ideals or factors that these cooperatives have followed to gain their success. In Canada, more cooperatives exist, but a lack of acceptance of new technologies over the past 20 years has led to a lag in automation and a reliance on labour. While outdated reports exist on starting an agricultural cooperative in Canada, there are still no updated reports that farmers could follow on a national or local scale. A lack of support from the Canadian Government has meant a monopolized cooperative arrangement with Saputo and Agropur being the two primary agricultural cooperatives nationally. The results indicate that there are commonly agreed upon 'success factors' and 'bottlenecks' among researchers in the Netherlands, over a span of 25 years of research. In Canada, the federal Government conducted interviews with industry and farmers on support for cooperatives across Canada, but little came out of these meetings. These results suggest that additional support for cooperatives in Canada is needed, and while Dutch researchers' 'success factors' were found, they cannot be directly applied to Canadian cooperatives because of policy and geography differences.
\end{abstract}

Keywords: cooperatives, value chains, agricultural systems, Canada, Netherlands 


\section{Introduction}

\subsection{Introduction}

This paper focuses on gathering an understanding of Canada's current agricultural cooperative climate when compared to the agricultural cooperative climate of the Netherlands. This, as Canada's intent to position itself as a global leader in the food and beverage processing sector is in-part based on the Netherlands' interest to expand Dutch cooperatives that operate within Canada (Wright and Reibeling, 2019, p. 3). It is worth noting that by definition of this paper, agricultural cooperatives refer to food and beverage cooperatives in both countries. Specifically, the term refers to common cooperatives in the Netherlands in which those cooperatives are vertically integrated and have found success in the food and beverage sector such as AB Werkt or Aviko, both from the Netherlands.

Currently, Canada's food and beverage supply chain is the second largest globally and includes those that supply primary and secondary processing through to retailers and consumers (Wright and Reibeling, 2019, p. 3). However, Canada's inability to challenge their growth in technology and innovation effectively, has meant a reliance on labour and a lag in automation (Wright and Reibeling, 2019, p. 3). In contrast, cooperative in Europe have had critical incidents such as policies, regulations and other barriers set forth from governments to prevent them from growing and innovating their cooperatives (Canadian Co-operative Association, 2009). Eventually, cooperative members joined together to fight against governmental interreference and restrictions and through time change occurred in the cooperatives, which meant less rules and regulations that restricted them from growth (Canadian Co-operative Association, 2009).

Canada has not taken a similar approach to that of Europe when developing a network for the cooperatives to thrive under. In part, it contributed to uncertainties regarding cooperative principles, the competing needs of cooperatives, philosophical disagreements, and career interests of the leaders running the cooperatives (Canadian Co-operative Association, 2009). Countries desire the trust and reputation of food quality and safety in Canada, not to mention the $\$ 98.1$ billion (CAD) food industry that has already been developed (Wright and Reibeling, 2019, p. 3).

When examining European food and beverage cooperatives in a given country, several countries stand out from the rest in the agricultural cooperative market share, according to an expert in the industry of Dutch agricultural cooperatives, Jos Bijman (2016, p. 3). Through his research, he has found that agricultural cooperatives in the Netherlands have a market share of $70 \%$, with the average market share of other countries at 40\%, as shown in Figure 1 (Bijman, 2016, p. 3). 


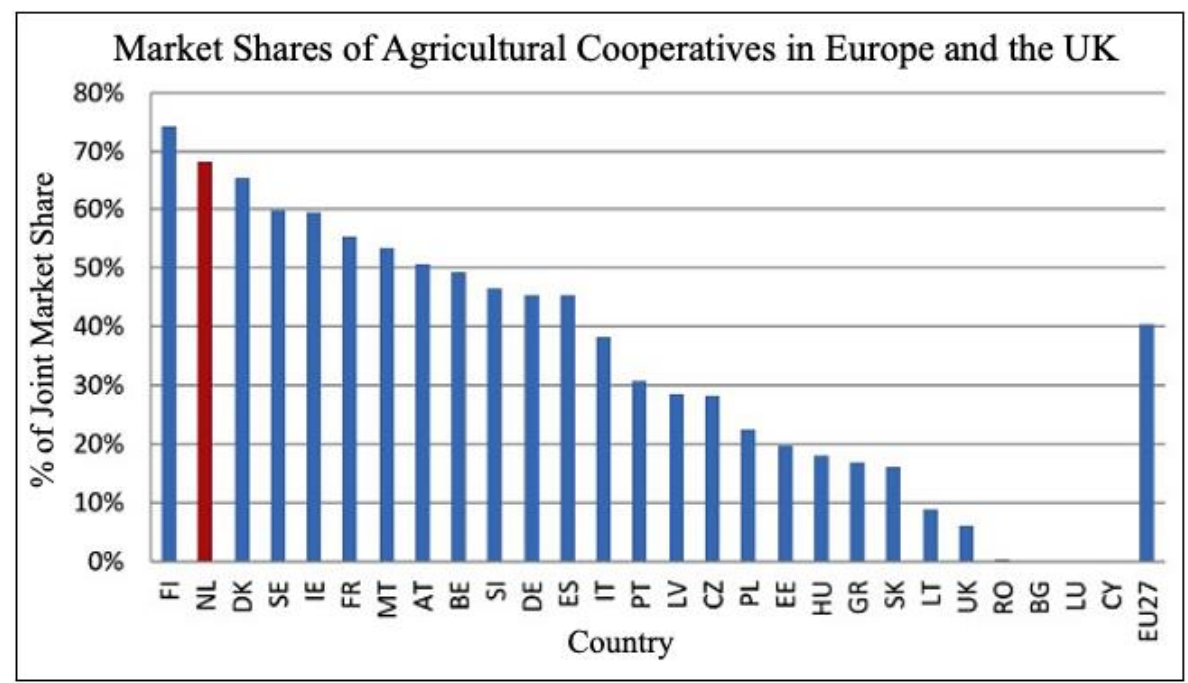

Figure 1. Market shares of agricultural cooperatives in Europe and the UK ${ }^{1}$

However, Finland is shown to have the largest market share of cooperatives in Europe; this begs the question as to why this paper is not focused on Finland rather than the Netherlands? To explain this, we must understand that the Netherlands has a similar financial valuation as Canada in the food and beverage industry but with half of the employees due to the automation and international trade the country does inside and outside of Europe (Wright and Reibeling, 2019, p. 3). For this reason, Wright and Reibeling assert that "there may be benefits in establishing a platform for collaboration between the Dutch and Canada in order to leverage the infrastructure, learnings and adoption of automation that the Dutch have effectively implemented" (2019, p. 3).

Complimentary to the industries inside knowledge, Bijman's research will be examined throughout this paper on how the Netherlands operates in the food and beverage cooperative sector. In fact, he describes the Netherlands as having a "rich tradition of cooperative development in agriculture" (Bijman, 2016, p. 3). He also mentions that agricultural cooperatives in the Netherlands have shown that they can successfully adapt to changes in market conditions, policies, and new technologies, which may help the future of the industry in Canada (Bijman, 2016, p. 3). In addition to Bijman's work, the author's experiences while living and travelling in the Netherlands determined that the success of Dutch agricultural

${ }^{1}$ Source: (Bijman, 2016, p. 3). Market shares are spread across cooperatives in dairy, sugar and potatoes, animal breeding, fruit and vegetables, and flowers (edible and non-edible). The information was collected in March of 2015 and represents all countries in the EU at the time of collection (FL (Finland), NL (Netherlands), DK (Denmark), SE (Sweden), IE (Ireland), FR (France), MT (Malta), AT (Austria), BE (Belgium), SI (Slovenia), DE (Germany), ES (Spain), IT (Italy), PT (Portugal), LV (Latvia), CZ (Czechia), PL (Poland), EE (Estonia), HU (Hungary), GR (Greece), SK (Slovakia), LT (Lithuania), UK (United Kingdom), RO (Romania), BG (Bulgaria), LU (Luxembourg), and CY (Cyprus)). EU27 refers to the mean data of all European Union countries minus the United Kingdom mean. 
cooperatives can be easily observed. Meanwhile, in Canada, the author found that agricultural cooperatives appear to be underdeveloped, particularly in the food and beverage industry.

As outlined by Wright and Reibeling (2019), success factors may not be easily adapted into the Canadian industry (p. 3). Rather, the fundamental learnings will be adapted from the Netherlands experiences in the industry thus far (Wright and Reibeling, 2019, p. 3). Using expert knowledge, peer-reviewed research, and common cultural knowledge learned from the author to aid in the research of this paper, it is a hope that a well-rounded paper will inform Canadian cooperatives on the current industry standard in a competitor's country.

\subsection{Comparative Research Problem and Sub-Questions}

Using research from Canada, the Netherlands, and abroad, this paper aims to bridge the gap between successful agricultural cooperatives in the Netherlands versus what is successful in Canadian ones. By comparing common policies, regulations, and key country factors such as infrastructure, labour industry studies and previously suggested key success factors from expert research, a strong comparison can be made.

The sub-questions that this paper intends to answer include the following:

1. Why are Dutch Agricultural Cooperatives successful in vertical coordination organization (i.e. input supplier to consumer)?

2. Is there a reason why Canadian farmers are not forming more agricultural cooperatives?

3. What are the incentives in forming agricultural cooperatives?

4. Are there common themes between researchers in the benefits of forming agricultural cooperatives?

\section{Cooperatives}

\subsection{The History and Development of Agricultural Cooperatives}

The first evidence of the modern agricultural cooperative model began with the founding of the cooperative movement in 1844 in Rochdale, England (Ontario Co-Operative Association, 2020). 28 artisans who worked at a cotton mill in the town faced low wages, miserable working conditions in the factory, and could not even pay for food or housing for themselves or their families' (Ontario Co-Operative Association, 2020). In response to the impoverishment they faced, they began to pool their money and resources together to afford necessities to sell to the community, which included only 4 items in the beginning, i.e. flour, sugar, oatmeal, and butter (Ontario Co-Operative Association, 2020). The artisans wanted their customers to be treated with respect, honesty, and openness as well as having a democratic say in the business through the option of combining profits if someone were to join in on the operations; the name of their cooperative was the Rochdale Equitable Pioneers Society (REPS) and became successful for the time (Ontario Co-Operative Association, 2020).

REPS founders examined their business model and developed what is now known as the 
Rochdale Principles (Ontario Co-Operative Association, 2020). These principles have changed over time but remain relatively similar in their context but simplified for present-day use for cooperatives worldwide. Outlined in Table 1 are the Rochdale Principles in the year 1860 vs the Principles in present day. The principles have changed over time due to changes in how cooperatives operate in an economy and why they are formed.

Table 1. The Rochdale Principles in 1860 vs Present Day

\section{The Rochdale Principles in 1860 vs Present Day}

\begin{tabular}{|c|c|}
\hline The Rochdale Principles in $\mathbf{1 8 6 0}$ & The Rochdale Principles in Present Day \\
\hline $\begin{array}{l}\text { 1. That capital should be of their own providing and } \\
\text { bear a fixed rate of interest. } \\
\text { 2. That only the purest provisions procurable should be } \\
\text { supplied to members. } \\
\text { 3. That full weight and measure should be given. } \\
\text { 4. That market prices should be charged and no credit } \\
\text { given nor asked. } \\
\text { 5. That profits should be divided pro rata upon the } \\
\text { amount of purchases made by each member. } \\
\text { 6. That the principle of "one member one vote" should } \\
\text { obtain in government and the equality of the sexes in } \\
\text { membership. } \\
\text { 7. That the management should be in the hands of } \\
\text { officers and committee elected periodically. } \\
\text { 8. That a definite percentage of profits should be allotted } \\
\text { to education. } \\
\text { 9. That frequent statements and balance sheets should be } \\
\text { presented to members. } \\
\text { (Bonner, 1961) }\end{array}$ & $\begin{array}{l}\text { 1. Voluntary and open membership } \\
\text { 2. Democratic member control } \\
\text { 3. Member economic participation } \\
\text { 4. Autonomy and independence } \\
\text { 5. Education, training and information } \\
\text { 6. Co-operation among co-operatives } \\
\text { 7. Concern for community }\end{array}$ \\
\hline
\end{tabular}

Created by Arthur Dodsworth

Increasingly, the modern agricultural cooperative model began to grow in Europe in the late nineteenth century, with the first cooperative legislation beginning in 1876, primarily in purchasing inputs and processing milk (Bijman, 2016). Until that point, most agricultural groups were informal and dealt in farm insurance, rural credit, cattle breeding, and the exchange of farming knowledge. Even with cooperatives' popularity, associations were forming parallel to the cooperatives as farmers and farmer unions saw the benefit in farmer-owned enterprises but were not convinced that the cooperative model was the method to do so. Only after 1920, most associations turned into cooperatives and therefore, the cooperative model became the leading model across the world (Bijman, 2016).

\subsubsection{The Netherlands}

In the Netherlands, the founding boom of agricultural cooperatives was formed between 1890 and 1930, as it was favourable for Dutch Agriculture to do so (Bijman, 2016). During World War 1, the Netherlands was neutral and benefited from the significant demand for agricultural products before, during, and after the war (Bijman, 2016). Although the cooperatives' economic qualities across the Netherlands has varied; Bijman (2016), suggests that it is not only about the economic elements of the cooperative but also the social element of collaboration between farmers, which should not be overlooked. 


\subsubsection{Canada}

The first agriculturally focused cooperative in Canada was formed by Alphonse Desjardins in 1900, with the establishment of a credit union in Lévis, Quebec (Fairbairn et al., 2000; Charlebois and Summan, 2014). He witnessed the high interest rates charged by the banks in Canada depressed the rural economy which made farmers' lives of difficult, and he wanted to change it (Fairbairn et al. 2000). He based his credit union on Friedrich Wilhelm Raiffeisen's model of building a cooperative that worked to educate and lead farmers to a better future (Fairbairn et al., 2000; Charlebois and Labrecque, 2009). In fact, Friedrich Wilhelm Raiffeisen was village mayor at the time that he founded the first rural cooperative in Germany which led to the discovery by Desjardins (Fairbairn et al., 2000). Desjardins wanted to develop a cooperative model that would shift the economic power to the smaller, rural farmers in Canada (Fairbairn et al. 2000). He sought to look past firms' needs and see the broader community's needs to bring the equality of economic power to farmers (Berge and Khawaja, 2016).

\subsection{Support for Agricultural Cooperatives}

The support for agricultural cooperatives that have formed since the Rochdale, England days has been only growing. Whether through government grants, subsidies, emergency benefits from the COVID19 Pandemic or private support, cooperatives have been receiving it. This is something that has previously been seen as a weakness for cooperatives when in fact, it has been a strength for them. However, agricultural cooperatives have a utilitarian objective because they are organized to support the business aims of farmers that partake in it (Cechin et al., 2013).

\subsubsection{The Netherlands}

The Dutch have had a benefit from the beginning in their support in operating agricultural cooperatives. They have benefitted geographically as mentioned previously, and from the financial and legal support they now have established between themselves and the government of the Netherlands. The Netherlands now has flexible cooperative laws that allow for a flexible internal governance structure, flexible financial structures, and allow for diversified activities the cooperatives can enter into (Bijman et al., 2012).

The flexible cooperative laws are helpful to agricultural cooperatives in the food and beverage sector as they can enter into extended activities related to the production of a given food or beverage product for retail sale. In fact, cooperatives in the Netherlands were not influenced by any competition laws regarding cooperatives until the end of the $20^{\text {th }}$ century (Bijman et al., 2012). This in part was due to the Netherlands' geographical size, which made the barriers for market entry low, especially for large food retailers (Bijman et al., 2012).

\subsubsection{Canada}

In Canada, the government has been slow to recognize the supports needed to help agricultural cooperatives operative effectively. In Fresco's words, consolidation within the Canadian food system has disconnected and disempowered consumers from the food system 
(2009). In Canada, the agricultural cooperatives have desired a change in the system due to a lack of consumer empowerment through democratic participation from cooperative members and educational programs for the public (Berge and Khawaja, 2016). However, these efforts to provide community members opportunities to take advantage of the cooperative model to further the economic system in their communities has gone largely unused in Canada (Berge and Khawaja, 2016).

Contradictory to Canada, many other countries have established successful networks that support agricultural cooperatives in sharing information, having government representation, and providing training to farmers who want to begin a food and beverage cooperative (Canadian Co-operative Association, 2009). Currently, the federal level of support for regulation and law is focused on support for livestock operations, commodity crops, food processing, and food safety standards (Irshad, 2010). The provincial-level is dedicated primarily to food safety and should have food-policy reform dedicated to supporting cooperatives (Irshad, 2010). As Irshad also highlights, the federal government can play an important role in the country-wide support for regulations and growing sustainable food and beverage products, but a national initiative is needed (2010).

\subsection{Vertical Coordination of Agricultural Cooperatives}

Vertical coordination can be defined in various ways according to the overarching theme to which it is being applied. In this instance, vertical coordination refers to the alignment of activities by 2 or more members of a cooperative that have a seller-buyer relationship; the more relationships that are existent in an agricultural cooperative, the better (Hendrikse and Bijman, 2002; Charlebois, Sterne and Buhr, 2014). Figure 2 illustrates what is meant by vertical coordination in relation to food and beverage cooperatives in this paper. The word value chain implies food and beverage products have value added along the supply chain, as appose to, little to no value being added along the chain. Figure 2 outlines member communication throughout the entirety of the value chain and reverse communication to provide feedback to specific members on how a value-added product may be adjusted to further benefit the members within the cooperative for example. In Canada, leveraging value-chain expertise towards Agri-food is still a non-traditional method according to LeBlanc, 2018. 


\section{Vertical Coordination and Integration}

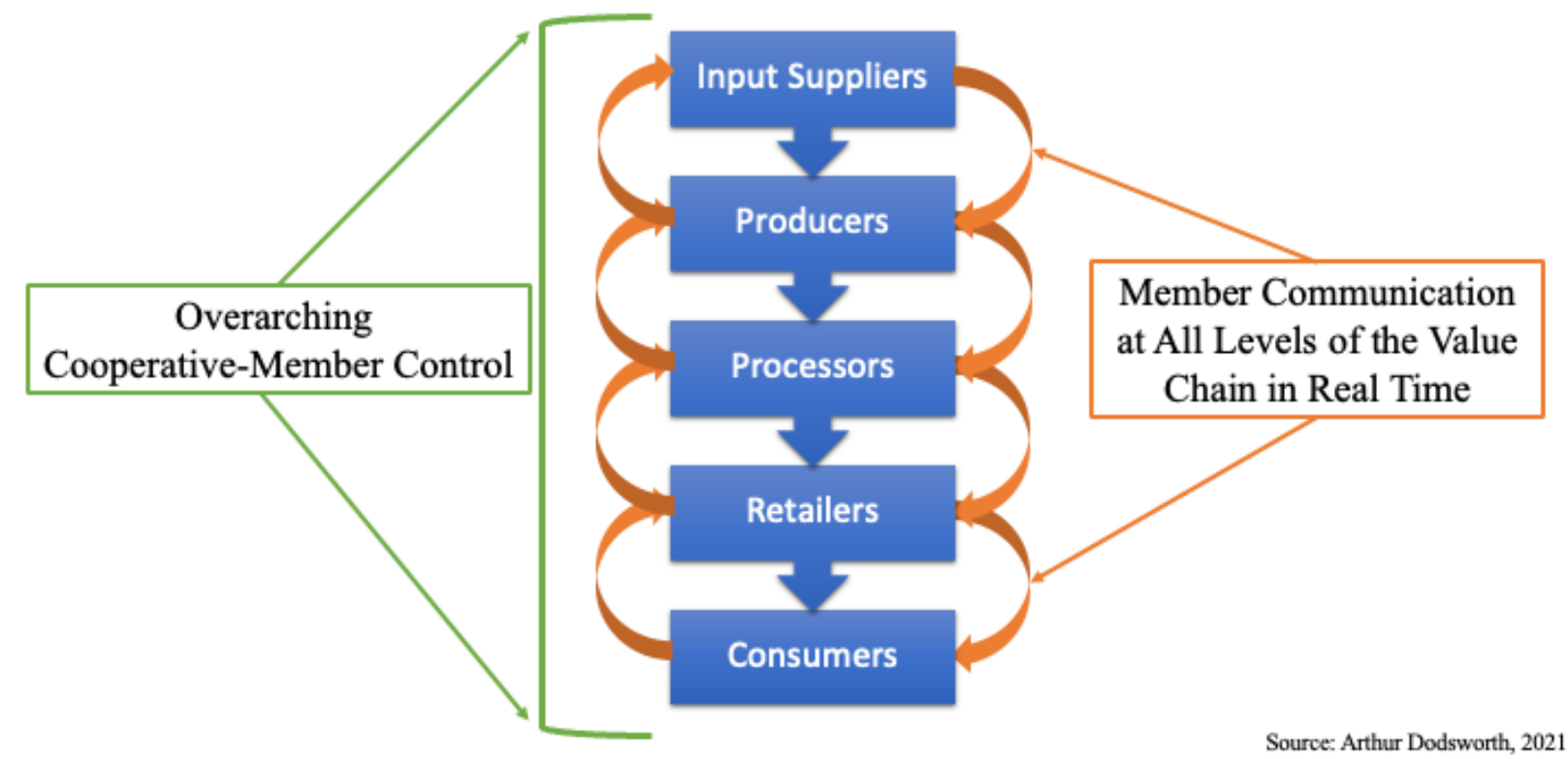

Figure 2. Vertical Coordination and Integration in the Value Chain

Vertical coordination within agricultural cooperatives is increasingly needed to effectively coordinate value chains according to Cechin et al., 2013). As Cechin et al. explains, to get vertical coordination to be less costly and for farmers to control their farming activities, it is important that all members of a cooperative are dedicated to a consumer-oriented strategy (2013). The member-cooperative relationship is something that Cechin et al. describes as being the key to integrated vertical coordination (2013). Challenges in the vertical coordination of a cooperative in the food and beverage sector, are particularly difficult because all members must have a collective action in the value chain process (Cechin et al., 2013).

\subsubsection{The Netherlands}

Bijman et al. claims that rising commodity prices, declining margins, and declines in scaling in primary production are all incentives for farmers to strengthen vertical coordination in the Dutch food and beverage supply chains (2012). Countries in the European Union are bound to cooperative framework, including EU regulations, national laws, and regional policies (Bijman et al., 2012). This is a stark comparison to Canada's law and regulation making methods, in fact all provinces have interprovincial trade barriers between them, and it hurts the economy (Cordy \& Bellemare, 2019).

Within Europe, Bijman \& Hanisch (2018) suggest that due to the highly concentrated retail market and dairy industry, it may be favourable for farmers and producers in vertical coordination. They go on to mention that the food-marketing structure of European food producers and cooperative relationships is highly intensive which in turn means increased efficiency in agricultural value chains (Bijman \& Hanisch, 2018). 


\subsubsection{Canada}

Vertical coordination in food and beverage value chains in Canada with member-control is relatively new in North America when compared to Europe. Although Canada is still developing vertical coordination within the country, the government of Canada classifies vertical integration of retailers still a non-traditional form of business (LeBlanc, 2018). Despite this, large retailers in Canada are beginning to vertically integrate. Several examples include:

- Walmart Canada - Vertically integrating to improve controls on supply and traceability including the use of blockchain technology.

- Amazon Canada - By purchasing Whole Foods and integrating expertise from existing Amazon data analytics, distribution channels and delivery options available, they can control the value chain in a way that most other companies cannot.

- Ikea - By having the $6^{\text {th }}$ largest food chain in the world, this company can leverage their supply chain knowledge and current lab research on insects and algae for human consumption.

Source: LeBlanc, 2018.

A study done in 1995 on vertical integration in Western Canadian grain pools which follow a cooperative structure, found that cooperative vertical integration may convey benefits to members indirectly through improved market access and increased producer margins (Harris, 1995). However, there is a lack of research that indicates significant vertical integration at the agricultural cooperatives in Canada.

\subsection{Success Factors as Previously Determined by Expert Research}

Between experts in the agricultural cooperative industry, the success factors that are suggested by each research vary. As this paper is a comparative analysis, it will compare these success factors both in the literature review through a text-based identification, and through table-based comparisons in the results, discussion, and managerial and policy implications sections, later in this paper. The Netherlands' success factors are researched more than Canadian success factors; it is still relevant when comparing the factors in each country but should be noted that more research is found in the Netherlands on this topic.

\subsubsection{The Netherlands}

In defining what makes an agricultural cooperative successful depends on the set circumstances in which it operates, among other things (Labrecque and Charlebois, 2006). From one year to the next, things can change very little to an upend of what was once normal in the world, as we have seen in 2020. In fact, agricultural cooperatives have been shown to increase trust and social capital with positive experiences over time, which may contribute to their formation (Bijman et al., 2012).

Table 2 outlines literature and primary information gathered in reference to key success factors that influence the success of a cooperative as well as the pitfalls in that success factor. 
The pitfalls are relevant to the literature in that they provide an alternative view to past research on what brings success to agricultural cooperatives several years ago versus present day, as outlined in the results section of this paper.

Table 2. Success factors and pitfalls of agricultural cooperatives in the Netherlands

\begin{tabular}{|c|c|c|}
\hline Phase & Success Factors & Pitfalls \\
\hline Identifying the opportunity & $\begin{array}{l}\text { Availability of external } \\
\text { market reports; presence of } \\
\text { external champions of the } \\
\text { sector }\end{array}$ & $\begin{array}{l}\text { Lack of agreement on the } \\
\text { problem to be addressed }\end{array}$ \\
\hline Building consensus & $\begin{array}{l}\text { Intensive support of other } \\
\text { cooperatives in same sector; } \\
\text { initial project planning } \\
\text { includes use of premier } \\
\text { consulting resources }\end{array}$ & $\begin{array}{l}\text { Cooperative approach not } \\
\text { appropriate for the problem; } \\
\text { other options more viable } \\
\text { than a cooperative }\end{array}$ \\
\hline Developing trust & $\begin{array}{l}\text { Experienced cooperative } \\
\text { development advisors are } \\
\text { available and utilized }\end{array}$ & $\begin{array}{l}\text { Limited understanding of } \\
\text { member's responsibility; lack } \\
\text { of confidence in leadership; } \\
\text { poor feasibility analysis }\end{array}$ \\
\hline $\begin{array}{l}\text { Securing } \\
\text { commitment }\end{array}$ & $\begin{array}{l}\text { Detailed, quality business } \\
\text { plan was developed as } \\
\text { member prospectus }\end{array}$ & $\begin{array}{l}\text { Unrealistic member } \\
\text { expectations; inability to } \\
\text { discipline members not } \\
\text { meeting responsibilities; lack } \\
\text { of member business volume }\end{array}$ \\
\hline $\begin{array}{l}\text { Involving } \\
\text { stakeholders }\end{array}$ & $\begin{array}{l}\text { Strong member commitment } \\
\text { required both in equity and } \\
\text { product delivery; well } \\
\text { qualified manager hired early } \\
\text { in development phase }\end{array}$ & $\begin{array}{l}\text { Underinvest in manager } \\
\text { compensation; low level of } \\
\text { equity financing; lack of } \\
\text { strategic plan }\end{array}$ \\
\hline Starting up & $\begin{array}{l}\text { Effective execution of } \\
\text { business plan; anticipation of } \\
\text { startup challenges (cash flow, } \\
\text { management, construction, } \\
\text { etc }\end{array}$ & $\begin{array}{l}\text { Unstable leadership } \\
\text { transition; poor marketing } \\
\text { plan; unqualified manager; } \\
\text { ineffective board of directors }\end{array}$ \\
\hline
\end{tabular}

Adapted by Arthur Dodsworth from Heuvelmans, 2013 


\subsubsection{Canada}

As discussed above, defining the success of an agricultural cooperative depends on several circumstances. What the research outlines in Canada is a more general sense of success factors related to cooperatives in Canada. Table 3 outlines the current literature in relation to key success factors that may influence the success of a cooperative in Canada. This table is organized differently when compared to the other tables in the section previous because the literature was found in a scattered matter, hence a more structured table is created below.

Table 3. Success factors/ideas suggested about agricultural cooperatives in Canada

\begin{tabular}{|c|c|c|c|}
\hline $\begin{array}{c}\text { Author(s) and } \\
\text { Date } \\
\text { Published }\end{array}$ & Success Factors/Ideas Suggested & $\begin{array}{c}\text { Page } \\
\text { Number(s) }\end{array}$ & $\begin{array}{c}\text { Referenced } \\
\text { Literature }\end{array}$ \\
\hline $\begin{array}{c}\text { Canadian } \\
\text { Co-operative } \\
\text { Association } \\
\text { (2009) }\end{array}$ & $\begin{array}{l}\text { 1. Leadership from agricultural } \\
\text { co-operatives in the } \\
\text { establishment and the operations } \\
\text { of the network } \\
\text { 2. Focus on core co-operative } \\
\text { mandate, values and structure } \\
\text { 3. Government support in terms of } \\
\text { policy focus and initial core } \\
\text { funding, but not dependence on } \\
\text { government funding } \\
\text { 4. Self-generated streams of } \\
\text { revenue to cover operating costs } \\
\text { 5. Clearly identified and } \\
\text { communicated services specific } \\
\text { to agricultural co-operatives } \\
\text { Credibility through agricultural } \\
\text { and co-operative expertise } \\
\text { 7. Agricultural } \\
\text { 8. Engaging members through } \\
\text { working groups, committees and } \\
\text { common projects that benefit the } \\
\text { whole } \\
\text { they are well represented, heard } \\
\text { Continuous communication and } \\
\text { meraction with the co-operative }\end{array}$ & p. 3-4 & $\begin{array}{l}\text { "Agricultural } \\
\text { Co-operative } \\
\text { Networks in } \\
\text { Canada" }\end{array}$ \\
\hline
\end{tabular}




\begin{tabular}{|c|c|c|c|}
\hline & $\begin{array}{l}\text { and understood, and actions on } \\
\text { the part of the network that } \\
\text { reflect this common } \\
\text { understanding } \\
\text { 10. Concrete benefits of increased } \\
\text { efficiency/ profitability that } \\
\text { benefits all members }\end{array}$ & & \\
\hline $\begin{array}{c}\text { Elvezio Del } \\
\text { Bianco, } \\
\text { Andrea } \\
\text { Harris, and } \\
\text { Ben Hyman } \\
\text { (2018) }\end{array}$ & $\begin{array}{l}\text { 1. Keep members informed and } \\
\text { involved } \\
\begin{array}{l}\text { 2. Use advisors and committees } \\
\text { effectively }\end{array} \\
\text { 3. Maintain good board-manager } \\
\text { relations } \\
\text { 4. Follow sound business practices } \\
\text { 5. Conduct effective meetings } \\
\text { 6. Forge links with other } \\
\text { cooperatives and organizations } \\
\text { 7. Common visions } \\
\text { 8. Skilled team } \\
\text { 9. Obtain enough relevant } \\
\text { development funding levels } \\
\text { 10. Develop effective } \\
\text { decision-making processes }\end{array}$ & p. $41-43$ & $\begin{array}{l}\text { "Agricultural } \\
\text { Cooperatives: A } \\
\text { Start Up Guide" }\end{array}$ \\
\hline
\end{tabular}

Created by Arthur Dodsworth

It is also worth noting that the Co-operative Development Foundation of Canada outlines the values and principles of forming cooperatives on their website (Co-operative Development Foundation of Canada 2020). Coincidentally, they are the same as the present-day Rochdale principles outlined in section 2.1 The History and Development of Agricultural Cooperatives.

\section{Research Design}

\subsection{Research Methods}

This paper will use qualitative data and use no primary data research in the methods. Rather, all data will be collected from secondary sources online and in peer-reviewed papers, using a grounded theory approach. The method for the results of this paper is to do a integrative review of the data collected with aspects of an annotated bibliography. It is also important to understand the literature review is adopted for the final results, therefore some updated research found originally in the literature review will be filtered into the final results as per an 
integrative analysis.

This decision to limit time gathering the results was in-part made due to the global COVID19 pandemic, which may delay primary research collection and delay the final report. It would also need ethics approval, which is something that the author of this report is restrained from doing due to commitments made in the Spring of 2021. Note that the materials for this paper will be found solely online because of the relevancy of the research and the current pandemic situation.

The following are the materials and methods that will be used for answering each sub-question:

\section{What are the incentives in forming agricultural cooperatives?}

Material: Existing research with reliable sources, peer-reviewed research, government websites.

Method: Document analysis.

Keywords for document analysis search: drivers, create, agricultural, cooperative(s), food, beverage, Netherlands, Canada.

Websites Utilized (but not limited to): ResearchGate.net , Elsevier.ca/Elsevier.com, TandFOnline.com, Novanet.ca, Wiley.com, Government.nl, Canada.ca.

2. Why are Dutch Agricultural Cooperatives successful in vertical coordination organization (i.e. input supplier to consumer)?

Material: Existing research with reliable sources, peer-reviewed research, government websites.

Method: Document analysis.

Keywords for document analysis search: Dutch, successful, agricultural, cooperative(s), vertical coordination, producer, consumer, retailer, processor, value chain, food, beverage, Netherlands.

Websites Utilized (but not limited to): ResearchGate.net , Elsevier.ca/Elsevier.com, TandFOnline.com, Novanet.ca, Wiley.com, Government.nl, Canada.ca.

3. Is there a reason why Canadian farmers are not forming more agricultural cooperatives?

Material: Existing research with reliable sources, peer-reviewed research, government websites.

Method: Document analysis.

Keywords for document analysis search: Canadian, farmer(s), cooperative(s), vertical coordination, producer, consumer, agricultural, retailer, processor, value chain, food, beverage, Netherlands. 
Websites Utilized (but not limited to): ResearchGate.net , Elsevier.ca/Elsevier.com, TandFOnline.com, Novanet.ca, Wiley.com, Government.nl, Canada.ca.

\section{Are there common themes between researchers in the benefits of forming agricultural cooperatives?}

Material: Existing research with reliable sources, peer-reviewed research, government websites.

Method: Document analysis.

Keywords for document analysis search: common, themes, researcher, benefits, forming, agricultural, cooperative(s), difference, Canada, Netherlands, research, food, beverage.

Websites Utilized (but not limited to): ResearchGate.net , Elsevier.ca/Elsevier.com, TandFOnline.com, Novanet.ca, Wiley.com, Government.nl, Canada.ca.

\subsection{Data Collection}

The qualitative data for this paper will be found using document analysis as the primary mode of research. Collection of data will include methods such as keyword searches, subject term searches, and publication types in databases which include but are not limited to Novanet, Elsevier, and ResearchGate databases, etc. (see methods above). International references inside and outside of the two countries of interest are important in providing a broad-view comparison between Canada and the Netherlands versus the world. Collection of the data will run from December 15, 2020 until February 18, 2021.

It is also worth noting that due to the nature of this secondary data study, inductive results are difficult to duplicate. In sorting through years of compiled research, small pieces of information were required from a range of sources that together form this comparative analysis, and therefor significant time would be needed to review the data in an organized manner. Additionally, the research process kept consistent with the keywords (as mentioned above), but those keywords did not keep to within specified databases. The research, due to natural limitations of the collection, was expanded to generic Google searches as well as Google Scholar. Please review the Research Design Diagram in Appendix 1 for more structure on the data collection and overall research design.

\subsection{Data Analysis}

The literature review and methods used will be developed using an integrative approach to review the relevant data into key findings and themes, with the most relevant information dedicated to answering the 4 sub-questions. Analyzing the qualitative data will require various forms of comparison using figures, charts, and tables. As mentioned in Appendix 1, the research design diagram, if the secondary research analyzed is not found to have updated information that aids in answering the sub-questions, the author will conduct more research from 1 agricultural cooperative Canadian member and 1 professional in the Canadian industry. These people will be contacted for the author to ask if they have any information related to recent research they may have on the topic. If for any reason no responses are reviewed, the 


\section{Macrothink

filtered results gathered from the literature review and any additional searches conducted will serve as the only basis for answering the sub-questions.

\section{Results}

While Bijman's research appears in both the Canada and Netherlands results, he attempts to understand the relevant information from each country and therefor the data is relevant.

\section{Sub-question 1: What are the incentives in forming agricultural cooperatives?}

\section{Globally}

Incentives for forming agricultural cooperatives according to the International Institute for Sustainable Development include the following:

- Farmers are able to collectively negotiate better contract terms and prices (FAO, 2012)

- Better access to a wide range of resources and services (FAO, 2012)

- Increased efficiency of smallholders and the efficient use of available resources by inspiring innovation, diversification and specialization in their members' businesses (International Labour Organization, 2001; United States Department of Agriculture (United States Department of Agriculture), 1990)

- Better access to markets (United States Department of Agriculture, 1990)

- Creation of productive employment (International Labour Organization 2011)

Source: Ruete, 2014

\section{Canada}

The principle for forming cooperatives as indicated by the Government of Canada is to meet a social or economic need that cannot be met by other groups or individuals in the sector (2018). The government continues to say,

"the co-operative option could prove to be the best legal choice because it is an organizational tool designed to meet the needs, and facilitate the operations, of both small and large groups of people."

Source: Government of Canada, 2018

The government also adds that the cooperative model may help keep a local business open or can assist in greater sustainability and corporate social responsibility (2018). Canadian cooperatives also have the ability to achieve a not-for-profit status to help communities in need of food and beverage.

\section{The Netherlands}

In the report Support for Farmers' Cooperatives; Final Report the authors suggest that an inverse relationship exists between strong cooperatives and the reduced governmental support offered in the Netherlands (Bijman et al., A, 2012). A European-wide study done 
investigating the potential links between support for farmers' cooperatives and the performance of these cooperatives relative to the market share indicate unclear correlations between support and performance (Bijman et al., A, 2012). The country-specific report on Support for Farmers' Cooperatives in the Netherlands says that the Common Market Organisation (CMO) for fruit and vegetables provides financial support from the European Union (Bijman et al., B, 2012). The funds from the CMO are provided through subsidies to Producer Organisations (PO) to increase sustainable production, improvement in product quality, and marketing activities (Bijman et al., B, 2012).

\section{Sub-question 2: Why are Dutch Agricultural Cooperatives successful in vertical coordination organization (i.e. input supplier to consumer)?}

Apparent decline in scaling and profit margins in agricultural production, along with an increase in market commodity prices indicate there are benefits for farmers to extend vertical coordination measures throughout the supply chain (Bijman et al., B, 2012). An example as outlined by Bijman et al. points out that family farmers in the pork industry of the Netherlands, who work under a profit-sharing contract, with purchases of inputs and the selling of animals is beneficial to the contracting organization (B, 2012). This option allows pig farmers to participate in economies of scale without advanced operations being developed (Bijman et al., B, 2012). This level of vertical coordination often leads to the outsourcing of marketing and purchasing activities of the organization as well (Bijman et al., B, 2012).

According to Bijman and Hanisch (2018), by increasing volatility it may mean tighter vertical integration for agricultural cooperatives. Volatility is something that the Netherlands is not known for in present day. In fact, they are one of the most competitive economies in the world with market stability at the forefront of their priorities. Bijman and Hanisch suggest that agricultural cooperatives, in particular the dairy industry, require tighter relationships between the farmers and the processors because processors want guarantees about product attributes and production methods and because they want to reduce transaction costs related to investments in specific human and physical assets in the cooperative (2018).

A decline in farmland diversity is also the result of vertical coordination in the Netherlands (Terwan et al., 2016). Switching from the degradation of farmland, the Dutch government switch focus to agri-environmental issues arising from having so many cooperatives active in the agriculture industry (Terwan et al., 2016). The Dutch government believes that there is a better value for money when cooperatives join together to help preserve the agri-environment (Terwan et al., 2016). Essentially, cooperatives are what many farmers depend on for their secured future success in the Netherlands, illustrated by Figure 3. 


\section{Authorities}

\section{Cooperatives}

\section{Land Managers}

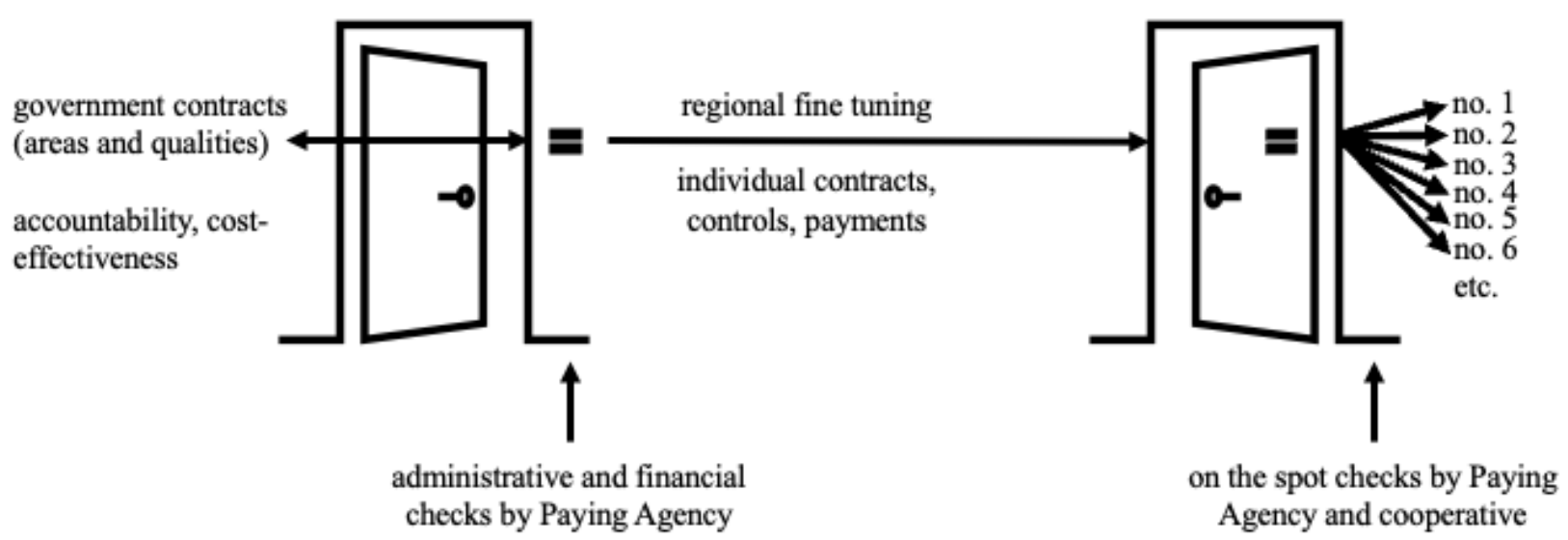

*Created by Arthur Dodsworth, adapted from Ministry of Economic Affairs, 2016

Figure 3. Front - back door of the Dutch agri-environment climate scheme with a key role for agri-environment cooperatives as financial beneficiaries

In addition, the structure of vertical coordination in Dutch agricultural cooperatives has been found to have 3 specific impacts as suggested by Berkum and Bijman, 2004:

- Quality improvements

- Yields and production levels

- Access to inputs and output markets

Sub-question 3: Is there a reason why Canadian farmers are not forming more cooperatives?

While Canada has more agricultural cooperatives when compared to the Netherlands, Canada has been slow to develop agricultural cooperative policies and regulations (Innovation, Science and Economic Development Canada, 2019). Although, in recent years the Canadian government has seen a local need for agricultural cooperatives to be vertically integrated to support local products from farmers in rural areas of Canada, the rules have consequences, in particular the lack of open provincial borders (Innovation, Science and Economic Development Canada, 2019).

In 2019, consultations were done to understand the barriers to agricultural cooperatives in Canada. Innovation, Science and Economic Development Canada conducted the meetings with 20 business associations, 15 cooperatives, 15 government departments, 6 individuals, and 1 academic institution (Innovation, Science and Economic Development Canada, 2019). What the government of Canada found included, accessing federal programs and services, raising awareness of the cooperative model and modernizing the cooperative sector data 
(Innovation, Science and Economic Development Canada, 2019). The results from the consultations also indicated that cooperative stakeholders responded favorably to questions around emerging opportunities such as the role of the agricultural cooperatives in reducing socio-economic and environmental issues in rural Canadian communities (Innovation, Science and Economic Development Canada, 2019).

\section{Sub-question 4: Are there common themes between researchers in the benefits of forming agricultural cooperatives?}

In summarizing the findings from Lorendahl (1996), Henehan \& Anderson (2001), Cook \& Burress (2009), Allahdadi \& Aref (2011), De Moor (2013), and Heuvelmans (2013), all conclude that with success factors, comes bottlenecks in these agricultural cooperative systems, in the Netherlands. Table 3 summarizes this literature into success factors with the subsequent bottleneck that could be faced for the applicable success factors mentioned.

Table 4. Summarized success factors and bottlenecks of agricultural cooperatives in the Netherlands

\begin{tabular}{l|l|l|l}
\hline$\#$ & Success Factors & $\#$ & Bottlenecks \\
\hline $\mathbf{1}$ & $\begin{array}{l}\text { Joint recognition of a common economic } \\
\text { problem }\end{array}$ & 1 & $\begin{array}{l}\text { Member issues: lack of clarity on rights } \\
\text { and duties, commitment }\end{array}$ \\
\hline $\mathbf{2}$ & $\begin{array}{l}\text { Cooperative is more effective than } \\
\text { individuals: economies of scale }\end{array}$ & 2 & $\begin{array}{l}\text { Too little financial means, } \\
\text { undercapitalization }\end{array}$ \\
\hline $\mathbf{3}$ & $\begin{array}{l}\text { Effective leadership and qualified } \\
\text { management }\end{array}$ & 3 & Management/leadership issues \\
\hline $\mathbf{4}$ & $\begin{array}{l}\text { Solid financial footing, member equity } \\
\text { investment }\end{array}$ & 4 & $\begin{array}{l}\text { Lack of feasible and adequate business } \\
\text { plan }\end{array}$ \\
\hline $\mathbf{5}$ & $\begin{array}{l}\text { Effective marketing and purchasing } \\
\text { strategies }\end{array}$ & 5 & $\begin{array}{l}\text { Dependency on government or certain } \\
\text { legislation }\end{array}$ \\
\hline $\mathbf{6}$ & Use of external advisors & 6 & N/A \\
\hline $\mathbf{7}$ & Commitment of members & 7 & N/A \\
\hline $\mathbf{8}$ & High quality feasible business plan & 8 & N/A \\
\hline
\end{tabular}

Heuvelmans, 2013

While Table 3 is summarizing the success-factors determined over the past several years, Heuvelmans explains that this is not outlining all of the research on agricultural cooperatives 
in the Netherlands but provides a relevant structure to what has been researched already.

\section{Discussion}

The objective of this study was to compare the success factors of Dutch agricultural cooperatives and Canadian agricultural cooperatives in the food and beverage sector. When analyzing the remainder of the secondary data from the literature review and conducting extended research on the results for the 4 sub-questions, little remained. All secondary data that pertained to the results of the sub-questions was included based on the relevancy of the information and the year it was conducted.

1 Agricultural cooperative Canadian member and 1 professional in the Canadian industry were contacted on any information related to recent research they may have on the topic. However, those contacted did not respond over more than 3 weeks in February 2021. This may be due to the last-minute efforts of the author to gather applicable and updated information on a relatively understudied topic in Canada. Hence, the sub-questions have limited results but are complimentary to the literature review in Chapter 2.

Additionally, inconsistent and outdated information was found on the sub-question results. While the data and information are not a definitive answer to each question, the results did indicate consistencies with the literature review. Some of the information that was expected to be found was, but more primary research should be done on the topic in Canada.

Overview of Sub-question 1: What are the incentives in forming agricultural cooperatives?

The global research on incentives shows that forming an agricultural cooperative with others is mutually beneficial to the individuals in the group. Members can create their own governance structures which can be highly favorable to those who want innovative products. While in Canada, the success of agricultural cooperatives in the West is known, this does not mean that other cooperatives across Canada have similar incentives. As the literature review outlined, the first cooperative to form in Canada was not in the West but rather the East; it is contrary to how the results indicate the success of the western cooperatives over eastern ones. In the Netherlands, incentives are based on financial support from the European Union with no other support from public funds. Results indicated no similarities between Canadian and Dutch incentives for forming cooperatives, which left incomparable data. There are relatively no direct incentives for forming a cooperative in the food and beverage industry in both countries.

Overview of Sub-question 2: Why are Dutch Agricultural Cooperatives successful in vertical coordination organization (i.e. input supplier to consumer)?

The Netherlands is successful in vertical coordination because of multiple actors throughout the value chain. Farmers in the dairy industry want direct information on how their products are being marketed and what products they produce in processing. The Netherlands has a government that supports vertical integration coordination between actors however there is no results that suggest the frequency of the communication. Although geographically the Netherlands is a centrally located European country, the literature review suggests that this 
was a reason for integration and coordination in the value chain. With limited information on this sub-question there are no primary reasons for the success of vertical coordination. Rather the result could be interpreted as a collective of policies and developments over the life of agricultural cooperatives in Europe and the Netherlands.

Overview of Sub-question 3: Is there a reason why Canadian farmers are not forming more cooperatives?

With Canada behind in automation in the agricultural sector, there is reason for a lack of development in advancing technology for processing food and beverage products. Unclear incentives from the government may deter farmers from forming cooperatives that are capital intensive. A lack of high paying jobs in the local agricultural processing sector, with little scalable innovation on farms, it is difficult to grow locally produced foods at reasonable prices for consumers. Farmers are detached from the product marketing and the supply chain process more so in Canada than in the Netherlands. This is contributed by the lack of supply chain transparency and large geography of Canada.

Overview of Sub-question 4: Are there common themes between researchers in the benefits of forming agricultural cooperatives?

There are common themes among researchers on why they are successful, but the information is vague. The themes that researchers agree on which bottleneck the progress of successfully forming an agricultural cooperative do not apply directly to one country or another. The research is lacking in recent years on success factors that have been defined by multiple authors with primary research. Jos Bijman, the expert as cited in both previous sub-questions 1 and 2 does not have direct results on common themes between researchers but his work included in the Literature Review may be sourced from multiple information sources. Canadian researchers have not explored this sub-question yet in the results found.

\section{Managerial and Policy Implications}

The results overshadow the underlying problems with policies and managerial economics of Canadian regulations towards agricultural cooperatives nationally. Consequently, Canada is seen as an upcoming leader in the food and beverage processing sector while equally lagging in the technology and innovations needed to grow the agricultural cooperative industry. This section of the paper will outline several issues identified with policy in the Canadian food and beverage sector that fit within the framework of agricultural cooperatives in Canada.

\section{Regulatory Challenges}

While Canada has been slow to change regulations in the food and beverage sector, there is private industry support throughout Canada (Binder Dijker Otte, 2018). Additional pressure is being put on food and beverage processors in Canada because of the increased need for transparency in food and beverage products (Binder Dijker Otte, 2018). Some would like to see Canada follow the international food standards for labelling to increase export opportunities with less work to change the labelling for specific export destinations (Binder Dijker Otte, 2018). 
Furthermore, Canada's internal trade barriers between provinces have meant fewer opportunities for agricultural cooperatives to reach the shelves at the retail level. In this sense, less competition allows other agricultural cooperatives to monopolize their provincial grocery stores with their products while smaller agricultural cooperatives struggle to get shelf space. Compliance costs alone serve as a deterrent for smaller actors in the industry new ideas that get shut out from big competition such as from Agropur or Saputo, the two largest dairy cooperatives in Canada (Binder Dijker Otte, 2018).

\section{Shifting Consumer Habits}

The ability for agricultural cooperatives to lean their strategies on ever-changing consumer habits is challenging with the current structures set in Canadian agricultural and processing policies. Reformulation of products to meet the consumers' needs means more investments in new product development and equipment at the production level (Binder Dijker Otte, 2018). With farmers making low margins already, only the largest food and beverage cooperatives can adapt quickly enough to formulate new product innovations cheaper than competitors, who are often local farmers in this case (Binder Dijker Otte, 2018).

\section{Emerging Trends in the Industry}

New trends in the food and beverage industry have seen an increase in the number of custom products available for a diverse consumer market (Binder Dijker Otte, 2018). Processing these new products means that agricultural cooperatives in Canada need to make smaller batches of products, have more attributes that are attractive to consumers and incur inventory carrying costs for specialized ingredients (Binder Dijker Otte, 2018). In addition, meals kits are a competition source for agricultural cooperatives in Canada because of their convenience and customization for each consumer (Binder Dijker Otte, 2018). Cooperatives could challenge this in high traffic areas, with products such as salads with multiple ingredients appealing to consumers while being less costly than going to the supermarket to buy a similar salad made in-store.

\section{Capitalizing on Opportunities}

Binder Dijker Otte suggest that through proactive planning, acceptance of new changes, providing feedback on proposed policies and regulation, and reaching out for professional help, agricultural cooperatives can have greater power over the structure of the agricultural food and beverage processing sector and cooperative agility (2018).

While challenges in Canada exist in the policies structured to limit internal trade and range from province to province, the ability for smaller cooperatives to grow is difficult. Without governmental support on automation, a reduction in domestic trade policies, and continual feedback and communication between private industry and government, the future of these policies affecting agricultural cooperatives will only grow to hurt the industry.

\section{Conclusions}

This report aimed to gather information surrounding the success factors of agricultural cooperatives in the food and beverage industries between the Netherlands and Canada. This 
report provided a comparative analysis between the two countries on aspects related to the building blocks of agricultural cooperatives and why they are formed. The results were collected by reviewing secondary sources of literature through the use of databases and government websites. While the collected information was not a significant amount, it provides a view into the current ideas on why agricultural cooperatives in the Netherlands are successful and what is different with Canadian agricultural cooperatives in respect to incentives and disadvantages of the Canadian sector.

Sub-question 1 asked, "What are the incentives in forming agricultural cooperatives?". Globally, agricultural cooperatives give farmers control over where their raw goods go. In Canada, the western part of the country has the most available resources for large agricultural cooperatives. Small agricultural cooperatives help keep local businesses open and may promote sustainability and corporate social responsibility. In the Netherlands, an inverse relationship between strong cooperatives and reduced governmental support exists despite not being the obvious answer that more support would lead to stronger cooperatives.

Sub-question 2 asked, "Why are Dutch Agricultural Cooperatives successful in vertical coordination organization (i.e. input supplier to consumer)?". Close relationships between farmers and processors reduce costs for both actors in the chain. Vertical coordination improves product quality, increases production and yield levels, and provides access to input and output markets. Organizing as a vertically coordinated cooperative, members can guarantee product attributes and appeal to consumers in a more controlled manner.

Sub-question 3 asked, "Is there a reason why Canadian farmers are not forming more cooperatives?". A lack of open provincial borders and slow progression of agricultural cooperatives' policies leaves gaps in regulation for Canadian agricultural cooperatives. Consultations found that accessing federal programs, modernizing cooperative sector data, and awareness of the cooperative model are all lacking in Canada. While no clear answer exists, there are common ideas expressed on the issue.

Sub-question 4 asked, "Are there common themes between researchers in the benefits of forming agricultural cooperatives?". The success factors found in the literature had outlined recognition of an economic problem, realizing a cooperative is more effective in economies of scale, having leadership and qualified management, member equity is stable, effective marketing and purchasing is conducted, incorporating the use of external advisors, having commitment of members, and having a feasible; high quality business plan all contributes to the success of an agricultural cooperative. The authors also indicated bottlenecks for most of the success factors, but those are not the focus of this report.

In essence, this report aimed at comparing the two food and beverage industries of the Netherlands with Canada in several key areas. While the answers are not entirely clear, it can be concluded that more research and improved data on agricultural cooperatives, in particular within Canada, will provide more concrete information and better comparison. This report considers that increasing the financial support, marketing, and primary research for agricultural cooperatives in Canada will improve the industry outlook. 


\section{Recommendations}

It is recommended that the Canadian government outline a national plan for agricultural cooperatives in the food and beverage sector which encapsulates incentives for members, the importance of vertical coordination, clear support systems in place for these types of cooperatives, and a common set of success factors or steps that have been proven to work for cooperatives not only in Canada but abroad. Additionally, the Canadian government must do more primary research on what works for cooperatives in Canada, conduct more surveys for feedback on current regulations in the industry, lift current provincial trade barriers throughout Canada, and conduct a review the on the effects of monopolistic competition on smaller agricultural cooperatives.

In a future study, more results need to be generated from primary research for an up-to-date, extended perspective on where the industry stands and consumer mindset. Results found by comparative analysis, in this case, have limited use. Hence, it is also recommended that future authors develop a foundation of information in both the literature review and the results for a strong comparison. With in-depth primary research and thorough online investigation, a better set of results for the basis of comparison may be uncovered.

\section{References}

Berge, S., \& Khawaja, M. (2016). Food Cooperatives in Canada. In Encyclopedia of Food and Agricultural Ethics, 1-7. https://doi.org/10.1007/978-94-007-6167-4_591-1

Bijman, J. (2016). Agricultural Cooperatives in the Netherlands: Key Success Factors. In International Summit of Cooperatives, October, 1-15. Retrieved on November 1, 2020 from https://www.researchgate.net/publication/308993047_Agricultural_Cooperatives_in_the_Net herlands_Key_Success_Factors

Bijman, J., \& Hanisch, M. (2018). Living apart together: How are member-cooperative relationships changing within European dairy cooperatives? In Humboldt University of Berlin. Retrieved on November 25, 2020 from https://www.agrar.hu-berlin.de/de/institut/departments/daoe/koopwiss/ifg/forschung/diss/bijm an-hanisch- living-apart-together-30-october-2018-2-edit-jos2.pdf

Bijman, J., \& Hendrikse, G. (2002). Ownership structure in agri-food chains. In American Journal of Agriculture. Econ. 84 (1), 104e119. https://doi.org/10.1111/1467-8276.00246

Bijman, J., Iliopoulos, C., Poppe, K. J., Gijselinckx, C., Hagedorn, K., Hanisch, M., ... Sanger, G. V. DER. A. (2012). Support for Farmers' Cooperatives; Final Report. In European Commission. Retrieved on February 4, 2021 from https://www.researchgate.net/publication/283418698_Support_for_Farmers'_Cooperatives_fi nal_report

Bijman, J., Poppe, K. J., Van der Sangen, G., \& Doorneweert, B. B. (2012). Support for Farmers' Cooperatives; Country Report: The Netherlands. In European Commission. $\begin{array}{lllll}\text { Retrieved on } & \text { November } & 10, & 2020 & \text { from }\end{array}$ https://www.researchgate.net/publication/283419565_Support_for_Farmers\%27_Cooperative 
s_Country_Report_The_Netherlands

Bonner, A. (1961). British Co-operation: The History, Principles, and Organisation of the British Co-operative Movement. Manchester: Co-operative Union. (No additional reference information found, was sourced in another paper with information included in this thesis dissertation).

Canadian Co-operative Association. (2009). Agricultural Co-operative Networks in Canada. In Canadian Co-operative Research Network. Retrieved on December 18, 2020 from https://ccrnrcrc.files.wordpress.com/2012/03/microsoft_word_-_ag_coop_networks_fmt_fina 1.pdf

Cechin, A., Bijman, J., Pascucci, S., \& Omta, O. (2013). Decomposing the Member Relationship in Agricultural Cooperatives: Implications for Commitment. In Agribusiness, 29(1), 39-61. https://doi.org/10.1002/agr.21321

Charlebois, S., \& Labrecque, J. (2009). Sociopolitical foundations of food safety regulation and the governance of global agrifood systems. Journal of Macromarketing, 29(4), 363-373. https://doi.org/10.1177/0276146709346255

Charlebois, S., \& Summan, A. (2014). Abattoirs, meat processing and managerial challenges: A survey for lagging rural regions and food entrepreneurs in Ontario, Canada. International Journal of Rural Management, 10(1), 1-20. https://doi.org/10.1177/0973005214526504

Charlebois, S., Sterne, R. H., \& Buhr, M. (2014). Sharing and preparing: cross-institutional, food security-based knowledge in Canada. International Journal of Sustainable Development \& World Ecology, 21(6), 532-539. https://doi.org/10.1080/13504509.2014.971905

Co-operative Development Foundation of Canada. (2020). What is a Co-op? In Co-Operative Development Foundation of Canada. Retrieved on December 20, 2020 from https://cdfcanada.coop/our-expertise/what-is-a-co-op/

Co-operatives Secretariat. (2012). Co-operatives in Canada. In Co-operatives and Mutuals Canada. Retrieved on February 16, 2018 from https://canada.coop/sites/canada.coop/files/files/documents/en/Special\%20COOP\%20commit tee\%20report\%20(EN).pdf

Dries, L., Germenji, E., Noev, N., \& Swinnen, J. F. M. (2009). Farmers, Vertical Coordination, and the Restructuring of Dairy Supply Chains in Central and Eastern Europe. In World Development, 37(11), 1742-1758. Retrieved on November 10, 2020 from https://doi.org/10.1016/j.worlddev.2008.08.029

Fairbairn, B., MacPherson, I., \& Russell, N. (2000). Canadian co-operatives in the year 2000: Memory, mutual aid, and the millennium (2000). In University of Saskatchewan. Centre for the Study of Co-operatives (Ed.). Saskatoon: Centre for the Study of Co-operatives, University of Saskatchewan. Retrieved on November 24, 2020 from https://usaskstudies.coop/documents/books,-booklets,-proceedings/canadian-co-ops-yr-2000. pdf 
Fairbairn, B. (1994). The Meaning of Rochdale: The Rochdale Pioneers And The Co-Operative Principles. In Occasional Papers 31778, University of Saskatchewan, Centre for the Study of Co-operatives. Retrieved on November 4, 2020 from https://ideas.repec.org/p/ags/uscoop/31778.html

Fresco, L. O. (2009). Challenges for food system adaptation today and tomorrow. In Environmental Science and Policy.12(4), 378-385. https://doi.org/10.1016/j.envsci.2008.11.001

Government of Canada. (2018). Information Guide on Co-operatives - Co-operatives in Canada. In Government of Canada. Retrieved on February 23, 2021 from https://www.ic.gc.ca/eic/site/106.nsf/eng/h_00073.html\#seven

Harris, A. L. (1995). Motives for the vertical integration and diversification of the Western Canadian prairie pools (T). Retrospective Theses and Dissertations, 1919-2007. In University of British Columbia. Retrieved on January 3, 2021 from https://open.library.ubc.ca/collections/ubctheses/831/items/1.0086728

Henehan, B. M., \& Anderson, B. L. (2001). Considering cooperation: a guide for new cooperative development. In Cornell University. Retrieved on January 28, 2021 from https://ecommons.cornell.edu/handle/1813/65922

Heuvelmans, K. (2013). Cooperative entrepreneurship; A study of new cooperative initiatives in the Netherlands. In National Cooperative Council. Retrieved on January 2, 2021 from https://www.cooperatie.nl/wp-content/uploads/2019/05/new-cooperative-initiatives-in-the-net herlands1.pdf

International Labour Organization. (2011). Cooperatives for people-centered rural development. In International Labour Organization. Retrieved on November 6, 2020 from https://www.ilo.org/employment/units/rural-development/WCMS_158998/lang--en/index.ht $\mathrm{m}$

Labrecque, J., \& Charlebois, S. (2006). Conceptual links between two mad cow crises: the absence of paradigmatic change and policymaking implications. International Food and Agribusiness Management Review, 9(1030-2016-82413), 1-29.

Leblanc, D. (2018). The Changing Landscape of Agri-Food Research Players AIC Symposium \& Government Impact Session. In Agri-food Innovation Council. Retrieved on December 14, 2020 from http://aic.ca/pdf/LeBlanc_AICNovember_2018.pdf

Ontario Co-operative Association. (2020). A Brief History of Co-ops. In Ontario Co-Operative Association. Retrieved on November 10, 2020 from https://ontario.coop/brief-history-co-ops\#: :text=Soon\%20afterwards\%2C\%20dairy\%20farm ers $\% 20$ established $\% 20 \mathrm{co} \% 2$ Doperative $\% 20$ creameries.\&text=As\%20early $\% 20$ as $\% 201887 \%$ 20the,farm\%20movement\%20in\%20the\%20Prairies.

Ruete, M. (2014). Inclusive Investment in Agriculture: Cooperatives and the role of foreign investment. In International Institute for Sustainable Development. Retrieved on January 3, 
2020

from

https://www.iisd.org/system/files/publications/inclusive-investment-in-agriculture-en.pdf

Terwan, P., Deelen, J. G., Mulders, A., \& Peeters, E. (2016). The cooperative approach under the new Dutch agri-environment climate scheme. In European Network for Rural Development. $\begin{array}{lllll}\text { Retrieved on } & \text { December } & 2020 & \text { from }\end{array}$ https://enrd.ec.europa.eu/sites/enrd/files/w12_collective-approach_nl.pdf

United States Department of Agriculture. (1990). Cooperatives benefits and limitations. In Rural Development U.S. Department of Agriculture. Retrieved on January 2, 2020 from https://www.rd.usda.gov/sites/default/files/cir1sec3.pdf

Wright, K., \& Reibeling, S. (2019). Opportunities for Collaboration between the Netherlands and Canada in the Food Processing Sector. In Netherlands Enterprise Agency. Retrieved on January 5, $2020 \quad$ from https://www.rvo.nl/sites/default/files/2019/02/opportunities-for-collaboration-between-the-net herlands-and-canada-in-the-food-processing-sector.pdf

International Labour Organization. (2001, June). 89th Session of International Labour Conference: Promotion of cooperatives. In International Labour Organization. Retrieved on $\begin{array}{llll}\text { January } & 5, & 2021 & \text { from }\end{array}$ https://www.ilo.org/public/english/standards/relm/ilc/ilc89/pdf/memo.pdf

Berkum, V. S., \& Bijman, J. (2004, September). The Impact of Foreign Investment on Supply Chains in ECA: Lessons from a Survey of Dutch Agri-food Multinational Companies. In LEI \& Wageningen UR. Retrieved on February 12, 2021 from https://www.researchgate.net/publication/40107652_The_impact_of_foreign_investment_on_ supply_chains_in_ECA_Lessons_from_a_survey_of_Dutch_agrifood_multinational_compan ies

Irshad, H. (2010, July). Local Food - A Rural Opportunity. In Alberta. Retrieved on $\begin{array}{llll}\text { November } & 26, & 2020 & \text { from }\end{array}$ https://www1.agric.gov.ab.ca/\$department/deptdocs.nsf/ba3468a2a8681f69872569d60073fde 1/593337cbd907813a8725782c0058ae97/\$FILE/Local-Food-A-Rural-Opp.pdf

FAO. (2012, November). Cooperatives: Empowering women farmers, improving food security. In Food and Agriculture Organization of the United Nations. Retrieved on $\begin{array}{llll}\text { November } & 25, & 2020 & \text { from }\end{array}$ http://www.fao.org/gender/gender-home/gender-insight/gender-insightdet/en/c/164572/

Binder, D. O. (2018, May 30). Challenges and opportunities in the food \& beverage industry - spring 2018. In Binder Dijker Otte Canada. Retrieved on February 22, 2021 from https://www.bdo.ca/en-ca/insights/industries/retail-consumer-business/food-beverage-challen ges-opportunities-spring-2018/

Cordy, J., \& Bellemare, D. (2019, January 17). Senate of Canada - Interprovincial trade barriers are a national embarrassment: Senators Cordy, Bellemare. In Senate of Canada. Retrieved on December

4 , 2020 from 


\section{Macrothink Institute ${ }^{\mathrm{TM}}$}

Journal of Agricultural Studies

ISSN 2166-0379

2021, Vol. 9, No. 3

https://sencanada.ca/en/sencaplus/opinion/interprovincial-trade-barriers-are-a-national-embar rassment-senators-cordy-bellemare/

Government of Canada. (2019, May 4). What We Heard: Motion-100 Consultations Co-operatives in Canada. In Government of Canada. Retrieved on November 19, 2020 from https://www.ic.gc.ca/eic/site/106.nsf/eng/h_00153.html

\section{Appendix}

Appendix 1: The Research Design Diagram

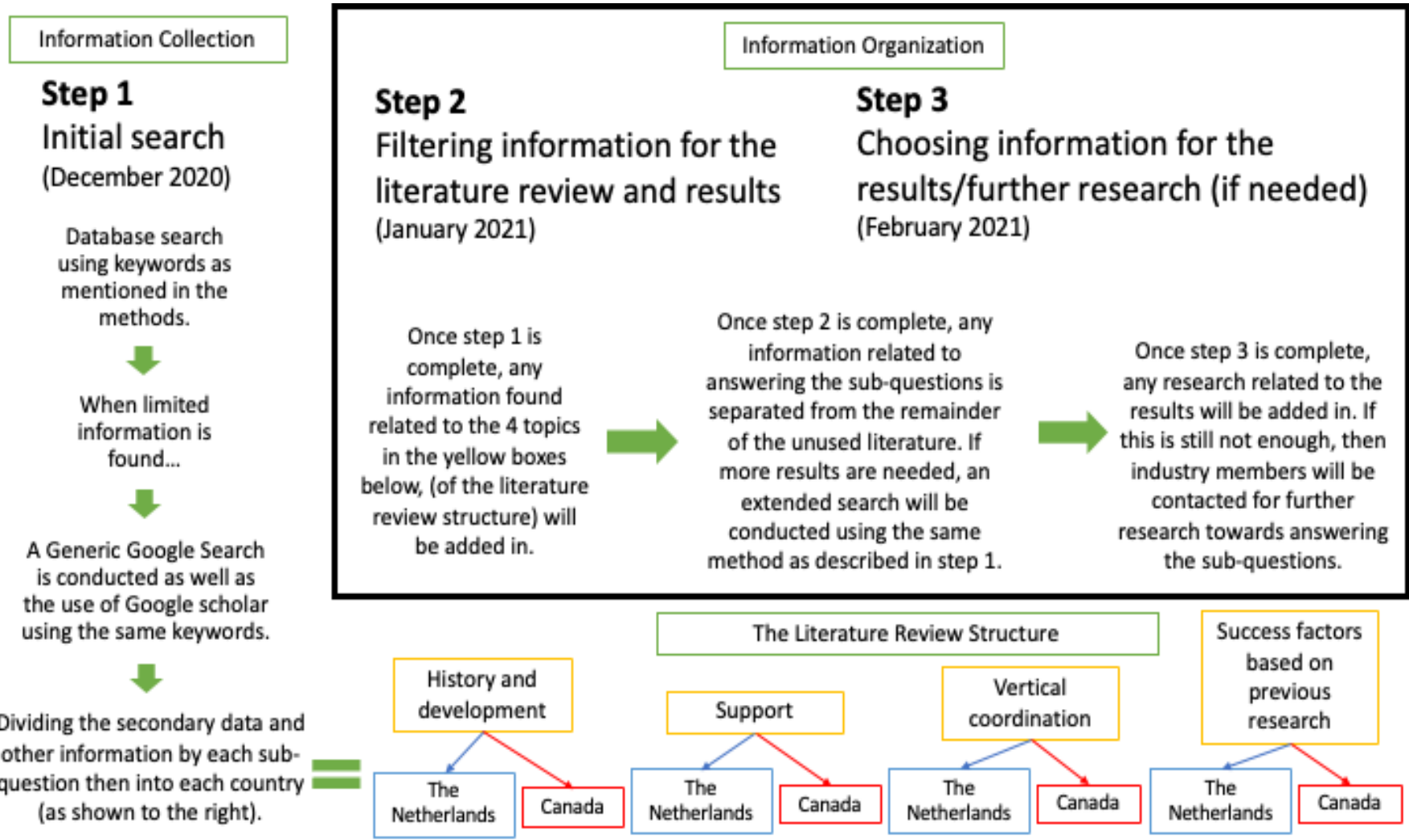

Source: Arthur Dodsworth, 2021

\section{Copyright Disclaimer}

Copyright for this article is retained by the author(s), with first publication rights granted to the journal.

This is an open-access article distributed under the terms and conditions of the Creative Commons Attribution license (http://creativecommons.org/licenses/by/4.0/). 